\section{Wages and Risk-Taking In Occupational Credit Unions: Theory and Evidence}

\author{
William R. Emmons \\ and Frank A. Schmid
}

redit unions are regulated and insured depository financial institutions dedicated to the saving, credit, and other basic financial needs of selected groups of consumers. ${ }^{1}$ Previous research has tended to suggest that credit unions operate inefficiently. In particular, given widely dispersed ownership and-in the case of employerbased or occupational credit unions- the presence of one or more sponsors primarily engaged in non-financial activities, there are reasons to believe that a managerial agency problem may be important.

In this article, we present a simple model of an occupational credit union in which the manager wishes to engage in expense-preference behavior. The sponsor must choose whether to accept this behavior and deduct the monetary equivalent from the manager's wage- what we call the Demsetz solution, as described in Demsetz (1983) - or to offer higher, so-called efficiency wages to discourage it. We show how wage expenses and risk-taking by the credit union are intimately connected.

We simulate the theoretical model to build intuition about the relationship among credit union size, wages, and risktaking. Then we provide empirical evidence that supports a link between the size of occupational credit unions and the levels of wage expense and risk-taking. In particular, larger credit unions tend to have higher wage expenses and take less risk.

We also document an important role for external control mechanisms, namely, local deposit-market competition. Wage expense is higher and risk-taking is lower in credit unions that face a less competitive local deposit market.

The article is organized as follows: The first section reviews previous research on credit unions. The second section presents our simple model of a credit-union sponsor who chooses both the compensation scheme for the credit-union manager and the amount of risky lending the credit union will do. This model nests both the Demsetz wage regime, in which the manager is allowed to shirk, that is, loaf on the job, but is paid a low wage, and an efficiency-wage regime, in which the manager is promised a high wage but is punished severely if caught shirking. The third section presents a nonstochastic simulation, comparative-statics results, and testable hypotheses. The simulation illustrates that the optimal choice of a compensation regime depends on the configuration of parameter values and exogenous variables that happen to exist. The fourth section contains a description of our empirical methods and results. The final section presents our conclusions. An appendix provides details on the empirical methodology, the dataset, and the variables we employ.

\section{PREVIOUS RESEARCH ON CREDIT UNIONS}

It is useful to distinguish between two main approaches taken in economic research regarding credit unions. One approach focuses on the legal structure of credit unions as consumer-owned cooperatives and explores how credit unions produce and distribute financial services. We refer to this branch of the literature as the structural
${ }^{1}$ See Srinivasan and King (1998) for an overview of credit unions and a discussion of current issues surrounding credit unions. 
approach to credit unions. The other approach - and the one this article follows most closely-focuses on the important yet largely extral egal and unregulated relationship between the management of a credit union and its members and sponsor(s). We call this the agency approach to credit unions.

\section{The Structural Approach to Credit Unions}

Early theoretical research on U.S. credit unions in the structural tradition includes Taylor (1971), Flannery (1974), Smith, Cargill, and Meyer (1981), and Smith (1984). These papers highlight an important conflict of interest that arises between members in determining the policies of the credit union. Savers-members who have deposits in the credit union but insignificant or no loans outstandingwant the highest possible deposit interest rate, while borrowers- members who have borrowed a significant amount of money from the credit union relative to their deposits- prefer the lowest possible lending rate. Clearly, these two objectives conflict. The question becomes, what policy will a given credit union follow?

Empirical research on whether credit unions are in fact saver-dominated or borrower-dominated finds mixed results. Flannery (1974) finds a tendency toward borrower domination in U.S. credit unions (i.e., low borrowing rates), Patin and $\mathrm{MCNiel}$ (1991) find evidence of saver domination (high deposit rates), while Smith (1986) finds no evidence of domination by either group. One might surmise from this inconclusive evidence that there is no general pattern among all credit unions with respect to rate-setting policy, and hence, domination by either savers or borrowers.

$M$ ore recent theoretical research in the structural tradition includes Besley, Coate, and Loury (1993), who analyze member incentives in rotating saving and credit associations in developing countries; Hart and Moore (1996, 1998), who model member incentives and conflicts in stock exchanges and cooperatives more generally;
Banerjee, Besley, and Guinnane (1994), and Emmons and Mueller (1998), both of whom study member incentives in cooperative banks in Germany; and Davis (1998), who looks at the long-term sustainability of cooperative financial institutions. Although modeling techniques have changed in recent years, the basic issues investigated by newer research still revolve around the governance and incentive structures implied by cooperative ownership of financial institutions.

Some recent empirical work in the structural tradition examines the operating efficiency of credit unions. Fried, Lovell, and Vanden Eeckaut (1993) find evidence of widespread operating inefficiency among credit unions of about the same degree as found by many other researchers studying other types of depository financial institutions. Extending the work of Fried et. al. (1993), Fried, Lovell, and Yaisawarng (1998) find that credit-union mergers may be effective in raising the performance of underperforming acquired institutions.

Emmons and Schmid (1999) adopt a somewhat different empirical approach to focus on the role of common bonds in credit unions. Using a semi-parametric estimation technique like the one used in this article, they show that the smaller the potential membership group, the higher member participation rates are in credit unions. These authors attribute the size-participation rate relationship to the declining ability of credit unions to satisfy member preferences as member heterogeneity increases. This result may point toward agency problems in credit unions that are aggravated as member attachment to the credit union declines, although they do not test for such problems explicitly.

\section{The Agency Approach to Credit Unions}

Credit unions have a comparatively weak governance structure compared to shareholder-owned financial institutions in the sense that no private individual or small group of individuals has the financial incentive to intervene strongly to discipline the management when the credit union's 
policies or performance go astray (Rasmusen, 1988, p. 397). This is because a one-person, one-vote governance structure quickly leads to free-riding incentives as the number of members increases. Reinforcing this tendency of monitoring incentives to weaken in larger credit unions is the lack of a disciplining role for takeovers since building a controlling coalition of credit-union members may be difficult. ${ }^{2}$

One implication of its weak governance structure is likely to be that a credit union's management becomes the de facto residual claimant to the institution's surplus. That is, even though a credit-union manager cannot profit by paying excessive dividends to large stockholders (including perhaps himself) or through gains on underpriced stock options, he may be able to convince the board of directors to pay him a large salary and grant him other nonwage perquisites of control, such as a luxurious office, extra staff, generous travel allowances, or simply a "quiet life." Hence, agency problems may be of the first order of importance in creditunion management and performance.

How can credit unions and other mutual financial institutions survive if they are subject to potentially large managerial agency problems? Two reasonable explanations have been offered corresponding to the period before and after the introduction of federal deposit insurance in the United States. Rasmusen (1988) suggests that mutual financial institutions thrived in the pre-deposit insurance era precisely because the manager had substantial power and discretion. An agency problem could help mutual financial institutions to survive because any risk-averse manager with substantial discretion could be expected to operate in a very conservative manner to preserve his position, salary, and consumption of perquisites. In contrast to stockholderowned banks, whose managers are likely to be large holders of the bank's stock and thus more interested in gambling with depositors' funds, credit-union managers have no way of obtaining option-like payoffs (i.e., pay-offs that are skewed toward large positive returns and protected against negative returns by limited liability). Rela- tively poorly informed and highly risk-averse depositors seeking a safe savings institution will find a mutual institution such as a credit union quite attractive, according to Rasmusen. Even though the manager engages in petty misappropriation of funds for his own use, he has a strong interest in avoiding risky investments that might jeopardize his position. Thus, compared to a stockholder-owned bank, a mutual bank would be preferred by uninformed and risk-averse depositors and might survive even though it operates inefficiently.

The advent of government regulation of banks and the creation of deposit insurance for virtually all depository institutions eliminates the advantage to risk-averse depositors of a mutual bank compared to a stockholderowned bank. In effect, the government assumes the risk borne previously by depositors, so the risk-taking of the bank is of no consequence to depositors. Depositors have no reason to prefer a risk-averse manager, and in fact, they become risk-loving if the safe return they are promised is higher as a consequence of the risk. Thus, the expansion of credit unions in the postdeposit insurance era must be due to something besides depositors' fear of bank risk-taking.

Hansmann (1996, pp. 259-60) suggests that employer-sponsored credit unions continue to thrive today because employers are willing to subsidize them:

Employers can also benefit from having a credit union for their employees. The credit union ties the employees more tightly to the employer, improves the employees' financial situation (and consequently their effective wage), and helps keep the employees out of financial difficulties that may interfere with their work or create bother for the employer (such as garnishment of wages). For these reasons employers have often helped promote the formation of credit unions, for example, by providing free office space and free time off to the employees who administer them.

\footnotetext{
2 These circumstances stand in stark contrast to those of a stockholder-owned firm (although there is ample evidence that governance of modern stock banks also is rife with inefficiencies). Individuals can assemble large and powerful blocks of stock ownership either to exert control over the existing management or to execute a takeover and replace the management.
} 
${ }^{3}$ For an overview, see Milgrom and Roberts (1992), or Ritter and Taylor (1997).

${ }^{4}$ Demsetz (1983) claims that his compensation scheme leaves both parties as well off as without shirking, thus eliminating the agency problem. This holds true if (and only if) the manager's shirking causes a loss to the sponsor that is equal to the benefit it offers to the manager. If the sponsor's loss exceeds the manager's benefit, the costs of running the firm are higher than in the absence of an agency problem. In the unlikely case that the sponsor's loss from shirking is lower than the manager's benefit, the manager's shirking leads to a Pareto improvement. This case does not pose an agency problem, so we do not consider it.
Thus, a key feature of occupational credit unions today may be the willingness of employers to subsidize their existence. Note that the managerial agency problem is likely to persist because the sponsor may not be well-suited (or motivated) to supervising a banking business.

Empirical work following the agency approach to credit unions and other mutually owned banks includes Akella and Greenbaum (1988), M ester (1989, 1991), Keating and Keating (1992), Schmid (1997), and Gorton and Schmid (forthcoming). All of these papers (and many others) document "expense-preference behavior," a positive relationship between more diffused ownership of a financial institution and the level of its expenses relative to those of institutions with more concentrated ownership.

We confirm the basic thrust of these results in our empirical investigations below. We also find evidence that the degree of local deposit-market competition is linked to the extent of the agency problem we observe.

\section{THE MODEL}

This section describes a model of an occupational credit union that nests two competing hypotheses regarding the compensation of agents who can engage in opportunistic behavior. It also allows us to derive hypotheses concerning the risktaking of the credit union. The model is based on the costly-state verification paradigm introduced by Townsend (1979). The problem to be solved is one of conflicting interests between the manager and the sponsor with respect to the manager's consumption on the job, which we term expense-preference behavior or "shirking." We assume that the sponsor can observe the manager's shirking but must wait for a government regulator to be able to prove it. An inspection occurs if (and only if) the credit union encounters financial distress. Although the regulator carries it out, an inspection adds to the operating costs of the credit union (as discussed below).

We consider two competing hypotheses. Demsetz (1983) suggests that firms may accept shirking by the manager and subtract the pecuniary equivalent of the expected amount of shirking from the manager's monetary compensation (wage). The manager's total compensation from the job still may be high enough to compete with other job offers.

The efficiency wage literature provides a competing hypothesis to describe how firms deal with an agency problem. ${ }^{3}$ In these models, the principal (the sponsor) increases the agent's (the manager's) opportunity costs of shirking to a level that makes shirking disadvantageous to the agent. This is accomplished by randomly inspecting the manager's performance and threatening to fire him if he is caught shirking. It is important to note that both the Demsetz pay structure and efficiency wage compensation are generally second-best solutions. That is, the total costs of running the firm are higher than in the absence of an agency problem. ${ }^{4}$

We consider one sponsor, the set of credit-union employees, and many creditunion members in a one-period model. For simplicity, we represent all credit-union employees with one employee, whom we call the manager. The sponsor and the manager are risk-neutral, while the members may be either risk-neutral or risk-averse without changing our results. In our model we assume that it is the sponsor who hires and (possibly fires) the manager, sets his wage, and defines the lending rulebook. Since, in reality, these decision rights reside in the board of directors of the credit union, we implicitly assume that the sponsor is in control of (or in complete agreement with) the board. We also assume that the manager is compensated at the end of the period. This allows the sponsor to tie the manager's wage to his behavior in a one-period model.

We assume that the benefit the manager enjoys from shirking, $G$, is discrete and known to the sponsor. We al so assume that the sole purpose of the credit union is to make loans. The task of the manager is to screen Ioan applicants according to the rulebook. The rulebook is public knowledge, which implies that the manager's decisions on loan applications are transparent to the 
sponsor and the members. We assume that the lending decisions are verifiable before the court at zero cost. This means that there is no agency problem between the sponsor and the manager with respect to lending, allowing us to model the lending decisions as if the sponsor made them himself.

We assume that the credit union cannot cover its costs without receiving subsidies from the sponsor, who is thus the de facto residual claimant of the credit union. For simplicity, we assume that the credit union's operating costs consist of management compensation and, in the event of financial distress, the sponsor's costs associated with inspection, C. In addition, if the manager shirks, the credit union loses an amount, $\mathrm{H}$, that corresponds to inflated expenses.

The sponsor enjoys a benefit from the credit union's lending that mirrors the productivity-enhancing effect this lending has on the sponsor's employees. There are two kinds of loans. First, there are safe loans, such as those that are fully collateralized. The benefit the sponsor receives from these loans equals the lump-sum amount B. It is optimal for the sponsor to define the lending rulebook such that all safe loans are made. These loans are riskless, so there are never any financial-distress costs associated with them. Risky loans are the second type of lending done by the credit union; these are less than fully collateralized loans. The sponsor attaches a value, $\gamma$, to each dollar of risky loan granted. We assume that additional lending al ways increases the total risk of the portfolio. This is because, for any given dollar amount of lending, L, the sponsor chooses the least risky loan portfolio. To increase lending, the credit union must take on lower-quality loans, and hence, more risk.

The total risk of the loan portfolio causes the credit union to become insolvent with some probability, p. The probability of distress is related to the risk of the credit union's loan portfolio by the cumulative normal density function $\Phi(\operatorname{lnL})$ with $I n L$ being the natural log of the amount of lending and $\phi(\mid n L)$ denoting the corresponding normal probability density function. The higher the risk, the more likely the credit union will enter distress, in which case the credit union is inspected by the regulator with certainty and the sponsor incurs costs of $C$.

Thus, in this model, the credit union's financial distress has two implications. First, inspection by the regulator reveals the true state of the credit union's cost situation. This means that the sponsor obtains legally verifiable evidence if the manager has shirked. Second, the sponsor incurs costs, $C$. These costs include the monetary equivalent of the damage to the sponsor's reputation both within and outside the firm, extra managerial and legal resources the sponsor has to allocate to the distressed credit union, and payments made by the sponsor to assist in the workout of the credit union.

The sponsor chooses between an efficiency-wage compensation scheme and a Demsetz-style compensation structure. In any regime, total compensation must amount to at least $W^{a}$, where $W^{a}$ is the manager's reservation wage. The reservation wage is the amount of compensation the manager can obtain in an alternative employment.

In the efficiency-wage regime, the sponsor can increase the manager's opportunity costs of shirking to the point that the manager becomes indifferent between shirking and not shirking. This is achieved by paying the manager a premium in addition to his reservation wage such that his benefit from shirking, $G$, equals the expected value of losing his job. The efficiency wage, $W^{e}$, is the sum of the reservation wage, $W^{a}$, and the wage premium, where $W^{e}>W^{a}$. The expected cost of losing the job is $\mathrm{p} \times\left(\mathrm{W}^{\mathrm{e}}-\mathrm{W}^{\mathrm{a}}\right)$. Since we use a one-period model, losing the job in an efficiency-wage framework is a metaphor for getting paid only the reservation wage $W^{a}$ at the end of the period. The manager will shirk if (and only if) the expected gain of expense preference behavior, $G$, is strictly greater than the expected loss from shirking, $p \times\left(W^{e}-W^{a}\right)$. In equilibrium, there is no shirking.

In the Demsetz compensation regime, there is shirking in equilibrium but there is no wage premium. Under the assumption 
${ }^{5}$ For instance, for $\gamma=0.7$, $\mathrm{G}=0.07, \mathrm{C}>3.3$, there is no positive value for $L$ that solves the maximization problem 1. For zero risky lending, the probability of inspection is zero. Consequently, the sponsor does not pay a wage premium, which means that the efficiency wage model does not apply.

${ }^{6}$ In the optimization problem 1 , the first-order condition for the optimal amount of lending reads $\phi(\ln L) \times\left(G / \Phi(\mid \ln L)^{2}-C\right)+\gamma L$ $=0$.

${ }^{7}$ In the case that the probability density function $\phi(\operatorname{lnL})$ is tangent to $\gamma L /\left(C-G / \Phi(I n L)^{2}\right)$, there is only a single value of L solving Equations 2a, $b$.

${ }^{8}$ It can be shown easily that for L going to infinity, the value of the sponsor's objective function $Z_{E}($ L) approaches infinity. Also, except for the case where the single-peaked probability density function $\phi(\ln L)$ is tangent to $\gamma L /\left(C-G / \Phi(\operatorname{InL})^{2}\right)$, there are two intersection points. Consequently, the optimum for the low value of $L$ must be a (local) maximum while the one for the high value of $L$ must be a (local) minimum. that the manager's benefit from shirking, $G$, is no greater than his reservation wage $W^{a}$, the sum of nonpecuniary and pecuniary compensation is the reservation wage in equilibrium. The sponsor has no reason to pay the manager more than it takes to attract him to this job.

The sponsor chooses the compensation scheme with the highest expected pay-off. If the sponsor's expected pay-off is negative, his participation constraint is violated and the credit union will not exist.

Thus, there are two considerations bearing on the sponsor's choice of compensation regime. First, if the sponsor switches from an efficiency-wage compensation to a Demsetz solution, he saves the wage-premium ( $W^{e}-W^{a}$ ) but will face increased operating costs caused by shirking, $\mathrm{H}$.

Second, changing to a Demsetz wage may affect the sponsor's expected pay-off by changing the optimal amount of lending, $L$. A change in $L$ affects the sponsor's benefit from lending as well as the probability that he will incur costs associated with the credit union's financial distress and inspection.

\section{The Efficiency-Wage Hypothesis}

If the sponsor installs an efficiencywage compensation schedule, he maximizes his expected pay-off, $Z_{E}$, by solving the following optimization problem:

(1a) $M a x \cdot Z_{E}=B-\left(W-W^{a}\right)-W^{a}-p C+\gamma L$ $\operatorname{lnL}, \mathrm{W}-\mathrm{W}^{\mathrm{a}}$

s.t.
(1b) $p \times\left(W-W^{a}\right) \geq G$
(1c) $p=\Phi(\operatorname{lnL})$
(1d) $L \leq L^{p}$
(1e) $\mathrm{L}>0$.

Condition $1 \mathrm{~b}$ is the manager's incentivecompatibility constraint. In equilibrium, this condition binds because the sponsor does not pay more than it takes to make the manager indifferent between shirking and not shirking.
Depending on the values for the parameter $\gamma$ and the exogenous variables $G, C$ and $L^{p}$, the model's solution may be one of two possible corner solutions or an interior solution. There also are strictly positive vectors $(\gamma, G, C)$ for which there is no positive amount of risky lending, $L$, that solves the model. ${ }^{5}$ In what follows, we concentrate on the interior solution to the model.

The interior solution for $L$ in the efficiency-wage model satisfies the first-order condition expressed in terms of the optimal probability of inspection $p^{*}$ :

$$
\Phi(\ln \mathrm{L})=\left(\frac{\mathrm{G}}{\mathrm{C}-\frac{\gamma \mathrm{L}}{\phi(\ln \mathrm{L})}}\right)^{\frac{1}{2}}
$$

Note that an interior solution requires C - $\gamma \mathrm{L} / \phi(\operatorname{InL})$ to be greater than zero.

An alternative way of writing the interior solution is

$$
\phi(\ln L)=\frac{-\gamma L}{\frac{G}{\Phi(\ln L)^{2}}-C}
$$

The first-order condition requires that $\mathrm{G} / \Phi(\operatorname{lnL})^{2}-\mathrm{C}$ is smaller than zero. ${ }^{6}$ Under this condition it is apparent that the righthand side (RHS) of Equation 2b is strictly convex in L. Since the probability density function is single-peaked, there are two values of $L$ solving Equations 2a, b. ${ }^{7}$ Only the smaller one satisfies the second-order condition, representing a (local) maximum. The larger of these two values of $L$ lies in a (local) minimum (see Figure 1 ). ${ }^{8}$ We define $L^{*}$ as the value of $L$ that solves Equations $2 a, b$ and satisfies the second-order condition.

Solving the sponsor's maximization problem for the efficiency wage premium, $W-W^{a}$, the interior solution is defined by:

(2c) $W^{e}-W^{a}=\left(G \frac{C-\gamma L^{*}}{\phi\left(\ln L^{*}\right)}\right)^{\frac{1}{2}}$. 
Again, an interior solution requires that the expression C- $\gamma \mathrm{L}^{*} / \phi(\operatorname{InL} *)$ is positive.

There are two corner solutions, in both of which constraint $1 d$ is binding for $L *$. The interpretation of a corner solution is that the credit union fully exploits its lending potential, i.e., $L=L^{p}$. This amount of lending determines the optimal inspection probability, p*, via Equation 1c, which in turn determines the optimal wage premium, $W^{e}-W$, by virtue of the binding incentivecompatibility constraint $1 b$.

One corner solution holds if C - $\gamma L^{*} / \phi\left(\ln L^{*}\right)>0$ and $L^{*}>L^{p}$. In this case, the optimal risk of the credit union's loan portfolio is $\Phi\left(\operatorname{InL} L^{p}\right)$, its highest possible value. The efficiency-wage premium, $\mathrm{W}^{\mathrm{e}}-\mathrm{W}^{\mathrm{a}}$, equals $G / \Phi\left(\mid n L^{p}\right)$, its lowest possible value.

The other corner solution occurs when C - $\gamma \mathrm{L} / \phi(\operatorname{lnL})$ is nonpositive. In this case, there is no positive efficiency-wage premium that solves the optimization problem. Since the first derivative of $Z_{E}$, with respect to the wage premium, is strictly negative for $\mathrm{C}-\gamma$ $\mathrm{L} / \phi(\operatorname{lnL}) \leq 0$, the optimal wage premium equals its minimum value, $G / \Phi\left(\operatorname{lnL} L^{p}\right)$, which leads to the first corner solution, discussed above. ${ }^{9}$

In summary, the efficiency-wage regime has one interior solution that satisfies the second-order condition (Figure 1). It also has two (identical) corner solutions. The values of the exogenous variables and the parameters determine whether the efficiencywage or the Demsetz compensation scheme will be better for a particular sponsor. The sponsor will install an efficiency-wage compensation regime if (and only if) the following two conditions hold: First, the relevant efficiency- wage solution is superior to the relevant Demsetz solution and, second, it satisfies the sponsor's participation constraint.

\section{The Demset Hypothesis}

The sponsor's optimization problem under the Demsetz hypothesis is:

(3a) $\operatorname{Max} \cdot Z_{D}=B-H-W-p C+\gamma L$ InL

\section{Figure 1}

\section{Solution to the Efficiency Wage Model}

Functions of $\mathrm{L}$

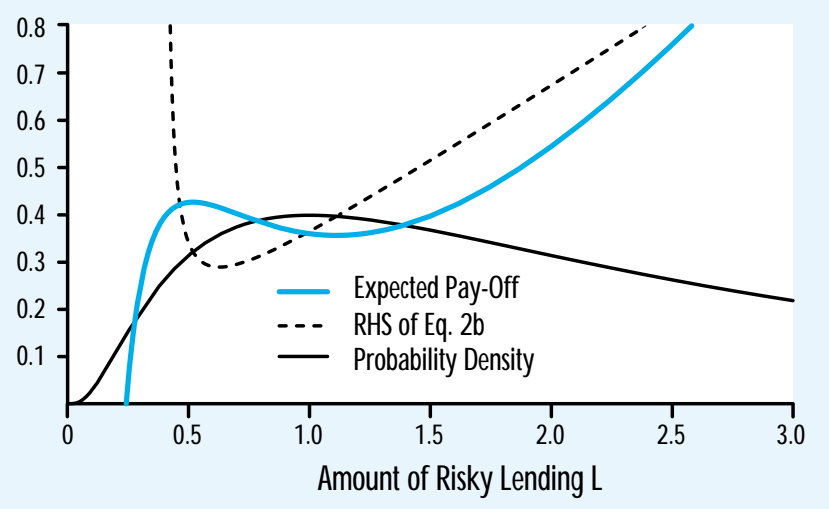

s. t.

(3b) $W=W^{a}-\min \left\{G, W^{a}\right\}$

(3c)

$$
p=\left\{\begin{array}{lll}
\Phi(\ln L) & \text { for } & L>0 \\
0 & \text { for } & L=0
\end{array}\right.
$$

(3d) $0 \leq L \leq L^{p}$.

Depending on the values for the parameter $\gamma$ and the exogenous variables $C$ and $L^{p}$, the model may have either one of two possible corner solutions or an interior solution. The interior solution satisfies the first-order condition:

(4) $\phi(\operatorname{lnL})=\frac{\gamma \mathrm{L}}{\mathrm{C}}$.

Since the right-hand side of Equation 4 is linear in $L$ and the probability density function is single-peaked, there are two values of $L$ that solve Equation 4. ${ }^{10}$ Only the smaller one, $L^{*}$, satisfies the secondorder condition (see Figure 2). ${ }^{11}$

One of two possible corner solutions occurs if $L^{*}>L^{p}$. In this case, the amount of risky lending takes on its maximum value $L^{p}$. Another corner solution ensues when there is no positive amount of lending, $L$, that solves Equation $4 .{ }^{12}$ In this case, the amount of risky lending and the probability of inspection are zero. The credit union might, nevertheless, exist if the benefit from
${ }^{9}$ When solving the optimization problem 1 for the wage premium $(W-W$ a $)$, the first derivative of the sponsor's objective function $Z_{E}\left(W-W^{a}\right)$ reads $-1+$ $G /\left(W-W^{a}\right)^{2} \times(C-\gamma L / \phi(\operatorname{lnL}))$.

${ }^{10}$ In the case where the probability density function $\phi(\operatorname{InL})$ is tangent to $\gamma L / C$, there is only a single value of $L$ solving Equation 4.

${ }^{11}$ Similar to the efficiency wage regime, we can argue that the sponsor's objective function $Z_{D}(L)$ goes to infinity for $L$ approaching infinity. Consequently, the optimum for the low value of $L$ must be a (local) maximum while the one for the high value of $L$ must be a (local) minimum.

12This holds, for instance, for $\gamma=0.7$ and $C>2.5$. 


\section{Figure 2}

Solution to the Demsetz Model

Functions of $L$

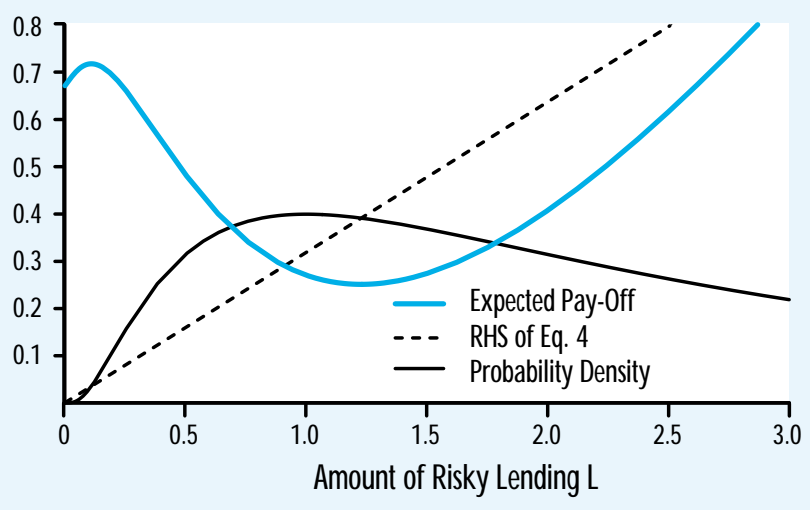

granting risk-free loans, $B$, is sufficiently high. For any solution, the pecuniary wage equals $W^{\mathrm{a}}-\mathrm{G}$, and the risk of the loan portfolio is independent of the benefit the manager reaps from shirking, $G$. N ote that in the Demsetz regime there is no benefit from verifying the true cost situation of the credit union since shirking is part of the compensation package.

The sponsor will install a Demsetz compensation scheme if (and only if) the following two conditions hold. First, the relevant Demsetz solution is superior to the relevant efficiency-wage solution and, second, it satisfies his participation constraint.

\section{Comparison of Compensation Regimes}

We compare Equation $2 b$ to Equation 4 and find that in interior solutions, $\phi(\operatorname{InL})$ is higher in the efficiency wage regime.

${ }^{13}$ We chose the following values for the exogenous variables: $B=1.9 ; G=0.07 ; H=0.3$; $L^{p}=3 ; W^{a}=1$. The value chosen for the parameter $\gamma$ was 0.7 . For Figures 1 and 2 we set the costs of distress, $C$, equal to 2.2.

${ }^{14}$ To help understand the mechanics of the model, Figures 1 and 2 were drawn without imposing the sponsor's participation constraint $Z_{E, D} \geq 0$ and the lending constraint $L^{*} \leq L^{p}$.

\section{SIMULATION}

In this section we present a simple nonstochastic simulation of the model to help build intuition and to derive hypotheses for the empirical analysis. First, we study the first-order conditions of the efficiency wage and the Demsetz solutions as displayed in Equations $2 b$ and 4 . Second, we present a comparative-static analysis of the effects of the sponsor's costs associated with financial distress and regulatory inspection, $C$, on the credit union's managerial compensation and risk-taking. ${ }^{13}$ Third, we derive two testable hypotheses regarding the pecuniary wage level and loan risk of credit unions.

\section{Optimums}

Figure 1 displays the two interior solutions to Equation 2b, the efficiency wage regime. It shows the probability density $\phi(\operatorname{InL})$, the right-hand side of Equation $2 \mathrm{a}$, and the sponsor's expected pay-off. The points of intersection between the solid and the dashed black lines mark (local) optima. As the objective function (blue line) shows, the left one is a local maximum while the right one is a local minimum. The corresponding graph for the Demsetz regime is displayed in Figure $2 .{ }^{14}$

\section{Comparative Statics}

Figure 3 displays the optimal pecuniary wage for the efficiency-wage regime and for the Demsetz regime across a range of values of $C$, the costs incurred by the sponsor when the credit union enters distress and is inspected. While the Demsetz pecuniary wage component is constant (and below the reservation wage), the efficiency wage is constant (and equal to the reservation wage) only for low values of $C$ (corner solution at $L=L^{p}$ ). The efficiency wage increases thereafter. At C $-\gamma L / \phi(\operatorname{lnL})=0$, the graph of the efficiency wage model has a discontinuity. As the graphs show, the efficiency wage model has no solution for sufficiently high values of $C$. That is, the sponsor will choose a Demsetz compensation scheme if the costs associated with distress and inspection are sufficiently 
high (but low enough to allow for an expected pay-off greater than zero).

Figure 4 shows the optimal risk of the credit union's loan portfolio as the cost of distress and inspection, $C$, is allowed to vary. For low levels of $C$, the risk level takes on its maximum value and is independent of the compensation regime (corner solutions at $L=L^{p}$ in both regimes). As $C$ increases, the optimal risk level in the Demsetz regime switches from the corner solution to the interior solution at $\mathrm{C}=\gamma L^{\mathrm{P}} / \phi\left(\operatorname{InL^{\mathrm {P}}}\right)$. In the efficiency wage regime, this changeover occurs at $C=\gamma L^{p} / \phi\left(\ln L^{p}\right)+G / \Phi\left(\ln L^{p}\right)^{2}$, a higher value of $C$ than in the Demsetz regime. For the range of $C$ in which an interior solution obtains, the optimal risk level decreases with an increase in the costs of distress. For sufficiently high values of $C$, there are no solutions for the efficiency wage model while the Demsetz model switches discontinuously to a corner solution with zero risk (because of zero risky lending). Comparing interior solutions across compensation regimes shows that for any given value of $C$, the risk level in the Demsetz regime is lower than in the efficiency wage regime.

Figure 5 displays the sponsor's expected pay-offs for the two compensation regimes. As in Figure 4, the graphs exhibit discontinuities at the values of $C$ that mark the border between corner solutions and interior solutions. For corner solutions at $L=L^{p}$, the expected pay-offs are linear in the costs of distress. The vertical difference between the two graphs equals the difference between the sponsor's loss from shirking and the wage premium. For interior solutions, the pay-offs are strictly convex in C. In the corner solution of zero risky lending in the Demsetz regime, the pay-off is independent of the costs of distress.

In the case displayed in Figures 3 to 5, the sponsor chooses an efficiency wage compensation structure for low values of $C$. As $C$ increases, the pecuniary wage level and the risk of the loan portfolio are left unchanged as long as the corner solution prevails. When, for a sufficiently high value of $C$, the efficiency wage switches from the corner solution to the interior

\section{Figure 3}

\section{Simulation: Effect of Changes in $C$ on Wage Level}

Pecuniary Wage

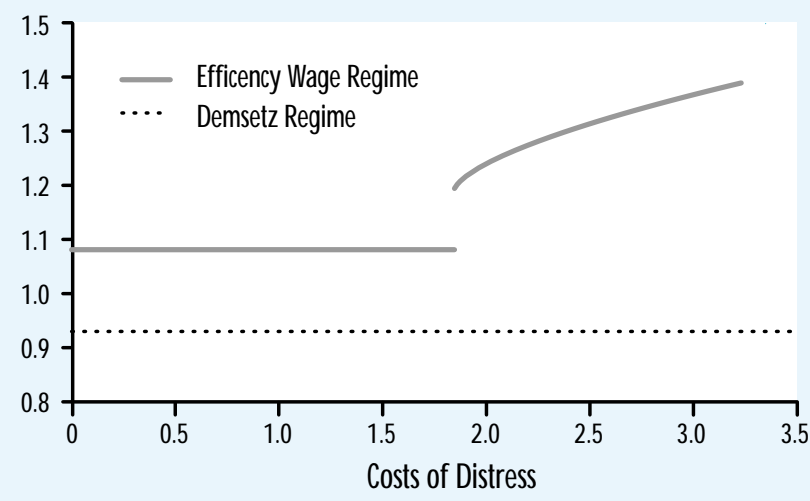

\section{Figure 4}

Simulation: Effect of Changes in $C$ on Risk-Taking

Risk of Loan Portfolio

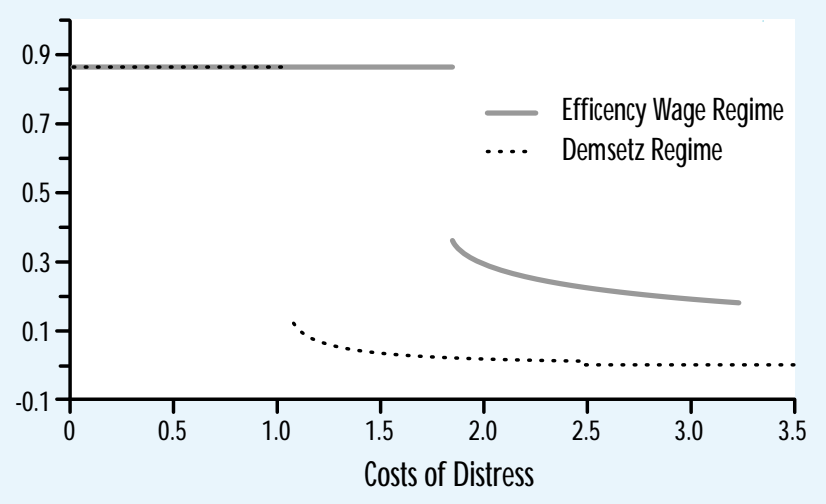

solution, wage and risk change discontinuously. While the wage increases, risk falls. With further increases in $\mathrm{C}$, the wage rises continuously and the portfolio risk declines continuously. When the switch to the Demsetz compensation regime eventually occurs, the pecuniary wage and portfolio risk drop discontinuously. While the wage adopts its minimum value and remains unchanged for further rises in $C$, the risk declines continuously as $C$ increases before 


\section{Figure 5}

Simulation: Effect of Changes in $C$ on Sponsor's Expected Pay-Off

Expected Pay-Off

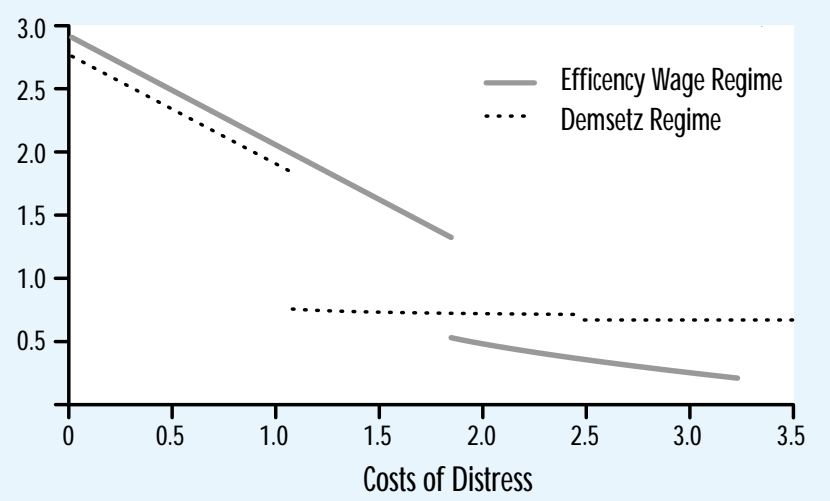

${ }^{15}$ This holds when the values of $G$ and $H$ that were used for Figures 1 through 5 are changed to 0.02 and 0.5 , respectively.

${ }^{16}$ This holds when the values of $G$ and $H$ that were used for Figures 1 through 5 are changed to 0.08 and 0.1 , respectively.

${ }^{17}$ This holds when the values of $G$ and $H$ that were used for Figures 1 through 5 are changed to 0.11 and 0.1 , respectively. sponding to zero risky lending.

Alternative sequences of regimes are possible as $\mathrm{C}$ increases. For instance, the efficiency wage regime may dominate the Demsetz regime over the whole range of values of $C$ for which it has a solution. ${ }^{15}$ is possible that for low values of $C$, the Demsetz regime dominates, followed by the efficiency wage regime for medium Demsetz regime dominates again. ${ }^{17}$

\section{Hypotheses} the credit union's costs of distress and inspection to its wage expense and risktaking. The first hypothesis concerns the predicted level of wages.

The impact of the costs of credit union distress and inspection on the credit union's wage expense is either:
1. Constant (if the Demsetz regime prevails for all values of $\mathrm{C}$ ), or

2. Nonincreasing (if the interior solution of the efficiency-wage regime never dominates, or if in the relevant range of $C$ the $D$ emsetz regime is not followed by an efficiency wage regime as $C$ increases), or

3. Nondecreasing (if in the relevant range of $C$ the efficiency-wage regime is not followed by the Demsetz regime as $\mathrm{C}$ increases), or

4. Hump-shaped (if the interior solution of the efficiency-wage regime is followed by the Demsetz regime as $C$ increases, or if the efficiency-wage regime is neighbored by Demsetz regimes on both sides).

it falls to zero in the corner solution correAlternatively, the Demsetz scheme may be superior to the efficiency wage compensation structure for all values of $C .{ }^{16}$ it also values of $C$, while for high values of $C$, the

We summarize the preceding discussion by stating two testable hypotheses relating

\section{HYPOTHESIS 1 (WAGE LEVEL)}

If we find evidence consistent with cases one or two, we would conclude that occupational credit unions do not use efficiency wages. If, on the other hand, we find evidence consistent with cases three or four, we would conclude that efficiency wages are being used by sponsors of occupational credit unions.

The second hypothesis concerns the credit union's risk-taking as predicted by the model.

\section{HYPOTHESIS 2 (RISK-TAKING)}

The risk of the credit union's loan portfolio is nonincreasing in the costs of credit union distress.

Notice that the risk-taking hypothesis is invariant to the compensation regime used by a credit union, in contrast to our predictions for wage expense. Thus, risk-taking does not allow us to test the efficiency-wage predictions against the Demsetz predictions, although it would allow us to reject the hypothesis that occupational credit unions employ either efficiency wages or a Demsetz compensation scheme. 


\section{EMPIRICAL METHODS AND RESULTS}

This section describes our dataset, the empirical methods we use, and empirical results. The Appendix contains more details on the first two of these topics.

\section{Dataset}

We examine a subset of all federally chartered and federally insured occupational credit unions during 1996. Table 1 provides a breakdown of our sample according to the type of membership group characterizing each credit union. Note that the table distinguishes between credit unions with a single common bond and those with multiple common bonds. Credit unions sponsored by a single manufacturing firm, for example, numbered 744 in our sample. Credit unions with multiple common bonds that predominantly were associated with manufacturing firms, numbered 821 , and so on, for the other membership types. We dropped credit unions whose sponsors were in the financial-services sector (TOM codes 20 and 50) because we could not obtain data on sectoral returns on equity. For more details, see the Appendix.

We examine balance-sheet data as of year-end 1996 and income data for calendar year 1996 for our sample of credit unions. Our dependent variables include a measure of the credit union's average wage level relative to local wages (WAGE) and the credit union's loan-loss allowance (ALLOWANCE). More specifically, WAGE is constructed by dividing a credit union's per-capita wage of full-time equivalent credit union employees by the average wage in the credit union's home county, and then taking the logarithm of this ratio. ALLOWANCE is the logarithm of the ratio of provisions made by a credit union for loan losses divided by its total loans. We dropped 14 (out of 2,628) observations because these institutions reported zero loan-loss allowances. Table 2 indicates that the median relative wage level of credit unions in our sample was about two percent above the local wage level, with the overall creditunion relative wage level almost precisely

\begin{tabular}{|c|c|c|}
\hline \multicolumn{3}{|c|}{$\begin{array}{l}\text { Distribution of Credit Unions by Type } \\
\text { of Membership }\end{array}$} \\
\hline $\begin{array}{l}\text { Number of } \\
\text { Credit Unions } \dagger\end{array}$ & $\begin{array}{c}\text { Type of Membership } \\
\text { (TOM) Codes } ¥\end{array}$ & Type of Membership \\
\hline 744 & 10-15 & Manufacturing \\
\hline 432 & $21-23$ & Services \\
\hline 821 & $40-49$ & Multiple group - primarily manufacturing \\
\hline 631 & $51-53$ & Multiple group - primarily services \\
\hline
\end{tabular}

matching local mean wage levels. Loanloss allowances, meanwhile, averaged 1.7 percent of total loans, with a median value of about 1.2 percent.

Independent variables we use include the logarithm of total assets (ASSETS), the logarithm of the number of members in the credit union (MEMBERS), the Herfindahl index of the local deposit market (HERF), the return on equity in the sponsor's twodigit SIC-code industry (ROE), the existence of multiple common bonds among the credit union's membership (MULTGROUP), the growth rate of real gross state product in the credit union's home state (GRREALGSP), and an indicator variable for sponsors in the service sector (SERVICES). The SERVICES variable appears only in the wage regressions because we expect systematic differences between wage levels in manufacturing and service industries. All other control variables are used in both hypotheses. Table 2 also gives descriptive statistics for ASSETS, MEMBERS, and HERF.

We use ASSETS and MEMBERS as proxies for $C$, the sponsor's costs associated with financial distress of the credit union and inspection by the regulator. This is because larger credit unions are more likely to be complex organizations and to offer a broad array of financial services to their members. Small credit unions typically offer a limited range of services such as savings and checking accounts and automobile loans (U.S. Treasury, 1997, p. 23). M ean- 


\section{Table 2}

\section{Descriptive Statistics}

\begin{tabular}{|c|c|c|c|c|c|}
\hline & Minimum & Median & Mean & Maximum & Standard Deviation \\
\hline Relative Wage Level † & $2.258 \times 10^{-2}$ & 1.019 & $9.963 \times 10^{-1}$ & 3.925 & $3.784 \times 10^{-1}$ \\
\hline Loan-Loss Allowance $\ddagger$ & $2.055 \times 10^{-4}$ & $1.178 \times 10^{-2}$ & $1.700 \times 10^{-2}$ & $3.600 \times 10^{-1}$ & $1.975 \times 10^{-2}$ \\
\hline Total Assets ${ }^{\dagger}$ & $4.300 \times 10^{4}$ & $5.031 \times 10^{6}$ & $2.266 \times 10^{7}$ & $1.947 \times 10^{9}$ & $7.797 \times 10^{7}$ \\
\hline Number of Members ${ }^{\dagger}$ & $4.500 \times 10^{1}$ & $1.581 \times 10^{3}$ & $4.694 \times 10^{3}$ & $1.672 \times 10^{5}$ & $1.104 \times 10^{4}$ \\
\hline Herfindahl Index † & $5.346 \times 10^{-2}$ & $2.001 \times 10^{-1}$ & $2.093 \times 10^{-1}$ & 1 & $9.391 \times 10^{-2}$ \\
\hline
\end{tabular}

while, 95 percent of large credit unions (more than $\$ 50$ million in assets) also offer mortgages, credit cards, loans to purchase planes, boats or recreational vehicles, ATM access, certificates of deposit, and personal checking accounts. Consequently, regulatory inspection is likely to be more difficult, time-consuming, and potentially expensive for the sponsor of a relatively large credit union. At the same time, interruption of a large credit union's activities is likely to be more disruptive to members- and hence also to the sponsor-because they may depend on these activities to meet a larger proportion of their financial needs.

One of the control variables we use is the ROE of the sponsor's industry sector. We cannot identify the sponsors from our dataset, but we are able to identify the sponsor's industry. The ROE of the sponsor's industry serves as a crude control for the parameter $\gamma$, the marginal valuation of credit union lending, in the sponsor's objective function.

\section{Empirical Method}

We test our hypotheses using a semiparametric model of credit-union performance of the form

(5) $y_{i}=x_{p i} \times \beta_{p}+f\left(x_{i}\right)+\varepsilon_{i}, \quad i=1, \ldots, n$

where $y_{i}$ is the $i$-th observation of the dependent variable; $x_{p i}$ is a row vector

${ }^{18}$ See Cleveland and Devilin, 1988; also see the Appendix of this paper for details. of the parameters of the linear part of the model; $x_{i}$ is a vector consisting of the $i$-th observation of the explanatory variables in the nonparametric part of the model; and $\varepsilon_{\mathrm{i}}$ is the $\mathrm{i}$-th realization of the error term. We use a semiparametric model to isolate independent variables whose effects we expect to be nonlinear, such as the number of members or total assets. The parametric part of the model contains independent variables whose effects may be approximately linear; these variables include the Herfindahl index, the sponsor's industry return on equity, and the growth rate of real gross state product in the credit union's state. In addition, indicator variables for the existence of multiple common bonds and for sponsor firms in the services industry are included in the parametric part of the regression. For more details on this methodology, see the Appendix.

\section{Results}

We test the two hypotheses that we derived from our model of occupational credit-union agency problems. First, we test the hypothesis that higher costs associated with financial distress impact the credit union's wage level. We also test for a negative relationship between distress costs and risk-taking by the credit union.

The series of plots presented in Figures 6-9 are "conditioning plots." 18 In each plot, one variable is kept at its median value while the other variable (identified on the abscissa) is allowed to vary. The graph displays the 
impact of this independent variable on the level of the dependent variable. In other words, the slope of the graph at a particular point reflects the marginal impact of the independent variable at that point. The intercept is not identified in regressions of this type, so only vertical distances are meaningful (not the level itself). The dotted lines are 90-percent confidence bounds.

Hypothesis 1: Wage Level. Figure 6 plots the partial effect of an increase in the log of total credit-union assets (a proxy for $C$ in the theoretical model) on the relative wage level of a credit union, where the relative wage is measured as the log ratio of a credit union's per-capita wage to the local average wage. We hold the number of members at its median value for each level of assets. It is clear that the relationship is non-linear, particularly at the smallest credit unions. We suspect that the high incidence of subsidies from employers and members who volunteer their time accounts for some of the unusual behavior of wages at the smallest credit unions. An upward slope in the relationship between total assets and the relative wage level is apparent, though, except for the very large credit unions. Judging from the wide confidence intervals for the largest institutions, however, the relationship is not estimated very precisely in this segment. The observed upward slope is consistent with the hypothesis that larger costs associated with financial distress translate into increased relative wage levels, as predicted by the interior solution of the efficiency wage model (Hypothesis 1, cases 3 and 4). Thus, the efficiency-wage theory is supported, while the Demsetz hypothesis- which predicts constant wages-is not.

Figure 7 basically makes the same point as Figure 6. The relative wage level of a credit union increases as the log number of members-another proxy for $\mathrm{C}$ - increases, holding the level of total assets at its median value for a given number of members. As before, the relationship is unusual and quite nonlinear at the smallest credit unions and appears to be upward-sloping over the full set of credit unions.

\section{Figure 6}

Wage Level and Total Assets

Partial Impact

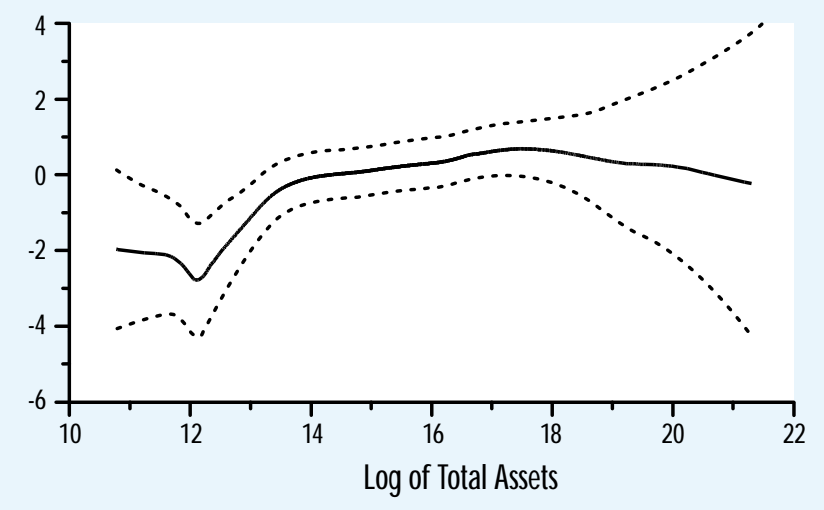

Figure 7

Wage Level and Number of Members

Partial Impact

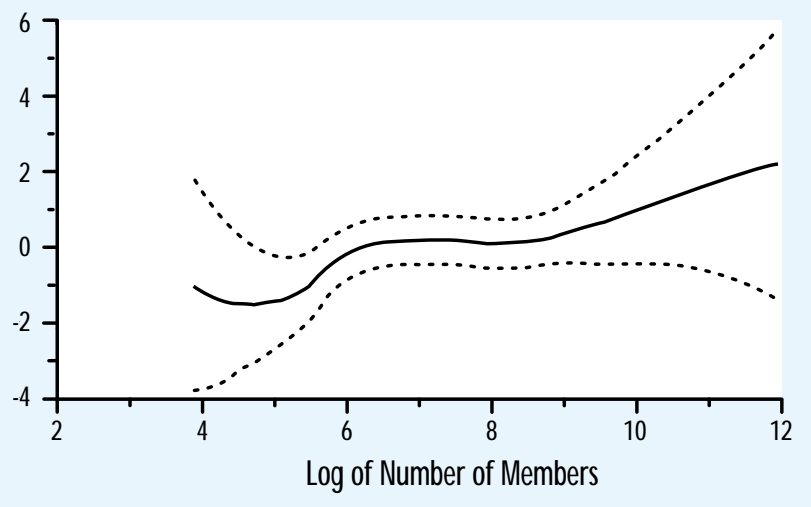

Table 3 presents results from the parametric part of the model. The significant positive coefficient on HERF indicates that, as the level of concentration increases in the local banking market, and presumably the intensity of competition decreases, the relative wage level of a credit union rises. If competition in the local deposit market is an important external source of control for agency problems, then higher concentration may indicate weak market discipline felt by the management. 
Table 3

Dependent Variable: Wage Level

\begin{tabular}{|c|c|c|}
\hline Independent Variable & Coef cient & t-statistic \\
\hline HERF & $2.734 \times 10^{-1}$ & $3.265 * * *$ \\
\hline ROE & $-1.695 \times 10^{-2}$ & $-3.402 * * *$ \\
\hline MULTGROUP & $2.426 \times 10^{-2}$ & 1.437 \\
\hline GRREALGSP & 1.057 & 1.349 \\
\hline SERVICES & $-5.276 \times 10^{-2}$ & $-2.893 * * *$ \\
\hline Number of Observations & 2628 & \\
\hline
\end{tabular}

*** Significant at the 1 percent level (two-tailed tests).

\section{Table 4}

Dependent Variable: Allowance for Loan Losses

\begin{tabular}{l} 
Independent Variable \\
\hline HERF \\
ROE
\end{tabular}

\begin{tabular}{ll} 
Coef cient & $t$-statistic \\
\hline-1.310 & $-6.742^{* * *}$ \\
$-1.066 \times 10^{-2}$ & -1.279 \\
$1.556 \times 10^{-2}$ & 0.438 \\
-7.387 & $-5.637^{* * *}$ \\
2614 &
\end{tabular}

*** Significant at the 1 percent level (two-tailed tests).

\section{Figure 8}

Allowance for Loan Losses and Total Assets

Partial Impact

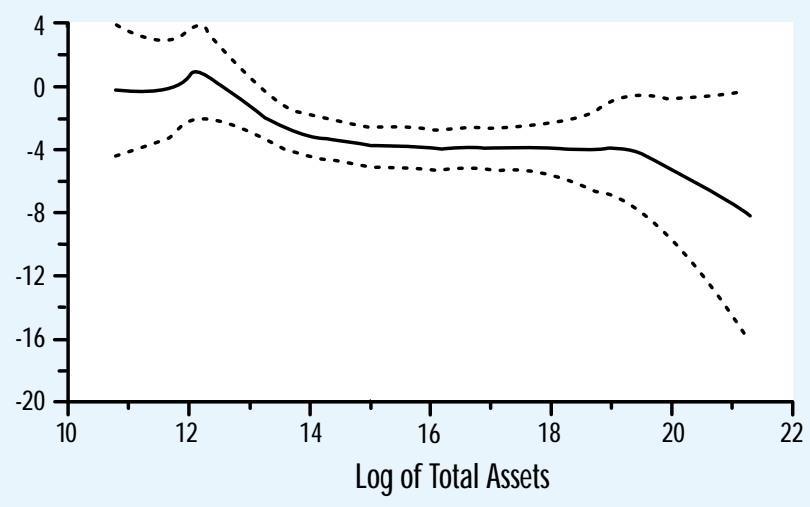

Hypothesis 2: Risk-taking. The intuition for this hypothesis is that sponsors try harder to avoid financial distress and regulatory inspection when they are more costly. This is accomplished by choosing a less risky loan portfolio. We use the log ratio of a credit union's allowance for loan losses to total loans as a proxy for risk-taking because this is an unambiguous measure of the amount of risk the credit union sponsor believes is in the portfolio.

Figure 8 plots the partial effect of an increase in the log of total credit-union assets on a credit union's loan-loss allowance, holding the number of members at its median value at each level of assets. The overall relationship is clearly downwardsloping, as predicted by our model. A nearly identical plot was obtained when we weighted the ratio of loan allowances to loans by each credit union's loan-to-asset ratio (not shown).

Figure 9 shows a similar result, this time allowing the log number of members in the credit union to vary while holding fixed the credit union's assets. A similar result was obtained when we weighted the ratio of loan allowances to loans by each credit union's loan-to-asset ratio (not shown). Thus, in both cases, our proxies for greater costs associated with financial distress (higher total assets and more members) are associated with less risky loan portfolios.

Turning again to the parametric part of the model, Table 4 provides one more piece of evidence supporting the predictions of our model. The significant negative coefficient on HERF indicates that, as the local banking market becomes more concentrated and presumably less competitive, a credit union's Ioan-loss allowance falls. This is consistent with the notion that credit unions that face less competition will take on less risk. In contrast to our wage regressions, the coefficient on the sponsor's industry ROE is not significantly different from zero in the risk-taking equation.

\section{CONCLUSIONS}

This article presents a theory that explores and provides evidence that is consistent with an efficiency-wage view of managerial agency problems at occupational credit unions. When costs associated with financial distress are likely to be high, we 
find that credit unions tend to have relatively high wage levels and their loan portfolios tend to contain relatively low levels of risk. We also find that local deposit-market competition and the profitability of the sponsor's industry are related to wages and risk-taking.

Despite some informational and incentive advantages associated with the common bond that unites occupational credit-union members, these institutions face many obstacles going forward. Recent legislation, which is widely seen as favorable for credit unions, is not an obvious panacea because the expansion of credit unions to encompass multiple common bonds threatens to dilute the advantages associated with these bonds. $M$ anagerial agency problems may take on even greater significance as the credit-union movement advances.

\section{REFERENCES}

Akella, Srinivas R., and Stuart I. Greenbaum. "Savings and Loan Ownership Structure and Expense-Preference," Joumal of Banking and Finance (September 1988), pp. 419-37.

Banerjee, Abhijit V., Timothy Besley, and Timothy W. Guinnane. "Thy Neighbor's Keeper: The Design of a Credit Cooperative With Theory and a Test," Quarterly Joumal of Economics (May 1994), pp. 491-515.

Besley, Timothy, Stephen Coate, and Glenn Loury. "The Economics of Rotating Savings and Credit Associations," American Economic Review (September 1993), pp. 792-810.

Cleveland, William S., and Susan J. Devlin. " Locally Weighted Regression: An Approach to Regression Analysis by Local Fitting," Journal of the American Statistical Association (September 1988), pp. 596-610.

, and _...... , and Eric Grosse. "Regression by Local Fitting: Methods, Properties and Computational Algorithms," J oumal of Econometrics (January 1988), pp. 87-114.

Davis, Kevin. "Incentive Compatible Governance in Cooperative Financial Institutions," Working Paper, University of Melboume, 1998.

Demsetz, Harold. "The Structure of Ownership and the Theory of the Firm," Journal of Law and Economics (June 1983), pp. 375-90.

Emmons, William R., and Willy Mueller. "Conflict of Interest Between Borrowers and Lenders in Credit Co-operatives: The Case of German Co-operative Banks," Working Paper, Federal Reserve Bank of St. Louis, 1998.

, and Frank A. Schmid. "Credit Unions and the Common Bond," Forthcoming in this Review, 1999.

\section{Figure 9}

\section{Allowance for Loan Losses and Number of Members}

Partial Impact

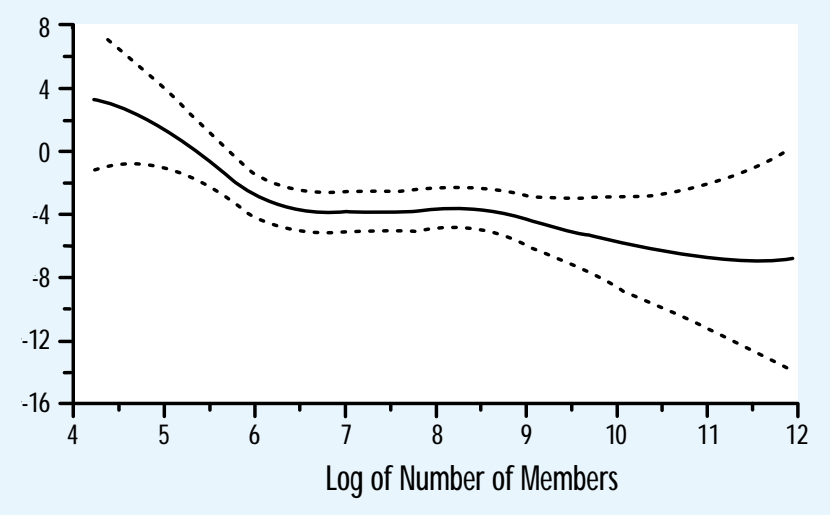

Flannery, Mark J. "An Economic Evaluation of Credit Unions in the United States," Federal Reserve Bank of Boston Research Report No. 54, 1974.

Fried, Harold 0., C.A. Knox Lovell, and Philippe Vanden Eeckaut. "Evaluating the Performance of U.S. Credit Unions," Journal of Banking and Finance (April 1993), pp. 251-65.

College, March 1998.

Gorton, Gary, and Frank Schmid. "Corporate Governance, Ownership Dispersion, and Efficiency: Empirical Evidence from Austrian Cooperative Banking," Forthcoming in Joumal of Corporate Finance.

Hansmann, Henry. The Ownership of Enterprise, Harvard University Press, 1996.

Hart, Oliver, and John Moore. "Cooperatives vs. Outside Ownership," Working Paper, Harvard University, 1998.

_....... , and _..._... "The Governance of Exchanges: Members' Cooperatives versus Outside Ownership," Oxford Review of Economic Policy (Winter 1996), pp. 53-69.

Hastie, Trevor J ., and Robert J. Tibshirani. Generalized Additive Models, Chapman and Hall, 1990.

Keating, Barry P., and Maryann 0. Keating. "An Empirical Estimation of the Degree of Expense Preference Behavior Between Credit Unions by Common Bond Type," Quarterly Review of Economics and Finance (Summer 1992), pp. 71-84.

Mester, Loretta J. "Agency Costs Among Savings and Loans," Journal of Financial Intermediation (June 1991), pp. 257-78.

. "Testing for Expense Preference Behavior: Mutual versus Stock Savings and Loans," Rand Joumal of Economics (Winter 1989), pp. 483-98. 
Milgrom, Paul, and John Roberts. Economics, Organization and Management, Prentice Hall, 1992.

Patin, Roy P., and Douglas W. MCNiel. "Benefit Imbalances Among Credit Union Member Groups: Evidence of Borrower-Dominated, SaverDominated, and Neutral Behavior?" Applied Economics (April 1991), pp. 76980 .

Rasmusen, Eric. "Mutual Banks and Stock Banks," Joumal of Law and Economics (October 1988), pp. 395-421.

Ritter, Joseph A., and Lowell J. Tayylor. "Economic Models of Employee Motivation," this Review (September-0ctober 1997), pp. 3-21.

Schmid, Frank A. "Eigentümerstruktur, Agency-Kosten und Untemehmenserfolg: Empirische Evidenz für österreichische Genossenschaftsbanken," Ifo Studien 43(4) (1997), pp. $491-519$.

Smith, Donald J. "A Test for Variant Objective Functions in Credit Unions," Applied Economics (September 1986), pp. 959-70.

_._. _. _. "A Theoretic Framework for the Analysis of Credit Union Decision-Making," Journal of Finance (September 1984), pp. 115568.

, Thomas F. Cargill, and Robert A. Meyer. "An Economic - Theory of A Credit Union," Joumal of Finance (May 1981), pp. 519-28.

Speckman, Paul. "Kernel Smoothing in Partial Linear Models," Journal of the Royal Statistical Society B 50(3) (1988), pp. 413-36.

Srinivasan, Aruna, and B. Frank King. "Credit Union Issues," Federal Reserve Bank of Atlanta Economic Review 83(3) (1998), pp. 32-41.

Taylor, Ryland A. "The Credit Union as a Cooperative Institution," Review of Social Economy (September 1971), pp. 207-17.

Townsend, Robert M. "Optimal Contracts and Competitive Markets with Costly State Verification," Journal of Economic Theory (October 1979), pp. 265-93.

U.S. Treasury Department. Credit Unions, U.S. Government Printing Office, 1997.

White, Halbert. "A Heteroskedasticty-Consistent Covariance Matrix Estimator and a Direct Test for Heteroskedasticity," Econometrica (May 1980), pp. 817-38. 


\section{DATASET, VARIABLES, AND ECONOMETRIC METHODOLOGY}

\section{The Dataset}

We draw our sample from the December 1996 semiannual Report of Condition and Income for Credit Unions (NCUA 5300, 5300S). This dataset includes all federally chartered and federally insured credit unions. The data include income statements covering the calendar year 1996 and balance sheets from year-end 1996. We use data for total assets and the number of members from year-end 1995 to avoid endogeneity.

We concentrate on the manufacturing and services sponsor groups among occupational credit unions. Thus, we exclude community, associational, and corporate credit unions, and occupational credit unions with sponsors of the following types: educational, military, federal, state, and local government. Type of Membership (TOM) classification codes are from the NCUA (Instruction N 0. 6010.2, July 28, 1995).

We use the following criteria to exclude credit-union observations:

- Missing TOM codes

- Activity codes other than "active"

- Number of members (or potential) members not greater than one; applies to actual and to lagged values

- N onpositive values for total assets or lagged total assets

- Number of employees given as zero

- Value for "employee compensation and benefits" given as zero.

\section{Definition of Variables}

Our dependent variables are restricted to be nonnegative. We use natural logarithms to ensure that these variables are not bounded and satisfy the assumption of normally distributed error terms. For data taken from the Report of Condition and Income for
Credit Unions, produced by the NCUA, the item numbers are in brackets.

Dependent Variables: 1) WAGE: Relative Wages of the Credit Union. To cal culate the relative per-capita wages of credit unions, we divide average per-capita wages of a credit union by the county-specific average annual wages for workers covered by the state and federal unemployment insurance programs (from the Bureau of Labor Statistics, Covered Employment and Wages (ES-202) Program). In a few cases, data were suppressed to protect the anonymity of an employer. We discard all credit unions in these counties.

The procedure is as follows: Divide employee compensation and benefits [CUSA 4137] by the weighted sum of the number of full-time employees [CUSA6047] and the number of part-time employees [CUSA6048]. We assign a weight of 0.5 to part-time employees and a weight of 1 to full-time employees. According to NCUA Form 5300, full-time is defined as 26 hours or more per week and part-time is 25 hours or less. Then, divide the per-capita credit-union wage by the per-capita wage in the county.

2) ALLOWANCE: Ratio of Loan-Loss Allowances to Loans. Divide allowance for loan losses [CUSA3123] by total loans [CUSA1263]. Fourteen (out of 2,628) observations were dropped due to a Tobit problem (reported zero allowances).

Independent Variables: Total assets (measured in dollars) and the number of members are lagged by one period and transformed into natural logarithms when used as regressors. Other independent variables include:

1) HERF: the Herfindahl index. We calculate county-specific Herfindahl indexes as measures of concentration in the local banking market. A Herfindahl index is defined as the sum of squared 
market shares, which we measure as the fraction of total bank deposits within a county based on FDIC Summary of Deposits data as of June 30, 1996 (available online at বhttp://www2.fdic.gov/sod/>). By definition, a Herfindahl index is greater than zero; with a maximum value of one.

2) ROE: Return on Book Value of Equity by Industry. ROE is defined as the ratio of net profit after taxes to net worth. First, we match SIC two digit codes with their corresponding TOM codes of credit unions. If a TOM code matches an odd number of SIC codes (including the case that it matched a single SIC code), we take the median ROE value of these industries. If the number of SIC codes is even, we take the mean of the two central ROE values of these industries. The data are taken from several annual volumes of Industry Norms and Key Business Ratios, published by Dun \& Bradstreet (Murray Hill, N.J.).

3) MULTGROUP: Multiple Common Bonds of M embership. We use an indicator variable set equal to one if the credit union has multiple common bonds of membership, and to zero otherwise.

4) GRREALGSP: Logarithmic Change in the Real Gross State Product. Log growth rates of real gross state product (GRREALGSP) are calculated from data provided by the U.S. Department of Commerce, Bureau of Economic Analysis, Regional Economic Analysis Division «ttp://www.bea.doc. gov/bea/dr1.htm>, to control for differing economic conditions facing credit unions.

5) SERVICES: Sponsor in the Services Sector. We use an indicator variable set equal to one if the sponsor of the credit union belongs to the services sector, zero otherwise. The classification is based on the TOM codes of the credit unions. Because we use an intercept in the nonparametric part of the regression, we drop the indicator variable for the manufacturing industry.

\section{Econometric Methodology}

We estimate a semi-parametric model of the additive partially linear type:
(A1) $y_{i}=x_{p i} \times \beta_{p}+f\left(x_{i}\right)+\varepsilon_{i}, \quad i=1, \ldots, n$

with

- $y_{i}$ : i-th observation

of the dependent variable

- $x_{\text {pi }}$ : row vector of the $i$-th observation of the explanatory variables of the linear (parametric) part

- $\beta_{\mathrm{p}}$ : (column) vector of the parameters of the linear part

- $x_{i}$ : vector of the $i$-th observation of the explanatory variables in the non parametric part

- $\varepsilon_{\mathrm{i}}$ : i-th realization of the error term.

We estimate the model following Speckman (1988). In a first step, y is smoothed on the variables in the nonparametric part of the semiparametric model. The "smoother" matrix, S, establishes a linear relationship between y and the estimate $\hat{y}$ :

$$
\text { (A2) } \hat{y}=S \times y .
$$

We use the smoother LOESS (locally weighted regression) as developed by Cleveland and Devlin (1988) and Cleveland, Devlin, and Grosse (1988). In contrast to univariate smoothers (e.g., kernel methods) that are used in conjunction with the backfitting al gorithm, this so-called locally weighted running-line smoother does not impose the restriction that the influence of the explanatory variables within the nonparametric part is additive ( $\mathrm{H}$ astie and Tibshirani, 1990, pp. 29-31). We use locally quadratic fitting with a smoothing parameter of 0.3 .

In a second step, the vector containing the dependent variable and the matrix of the explanatory variables of the parametric part are adjusted for the influence of the nonparametric part:

(A3a) $\tilde{y}=(I-S) \times y$ 
(A3b) $\tilde{X}_{p}=(I-S) \times X_{p}$

with I being the identity matrix.

In a third step, the vector $\beta_{\mathrm{p}}$ is

estimated using ordinary least squares:

(A4) $\hat{\beta}_{p}=\left(\tilde{X}_{p}^{\prime} \tilde{X}_{p}\right)^{-1} \times \tilde{X}_{p}^{\prime} \tilde{y}_{\text {. }}$

As Speckman (1988) has shown, the bias of the estimator $\beta_{\mathrm{p}}$ is asymptotically negligible.

The estimated impact of the explanatory variables in the partially linear model is

(A5) $\hat{f}_{p}=S \times\left(y-X_{p} \hat{\beta}_{p}\right)$.

Thus, we obtain as the estimated vector of the dependent variable the following:

(A6) $\hat{\hat{y}}=X_{p} \hat{\beta}_{p}+\hat{f}_{p}$.

It is then straightforward to show that $\hat{y}$ is a linear function in $\mathrm{y}$ :

(A7a) $\hat{\hat{y}}=L_{s} \times y$

with

(A7b) $L_{s}=X_{p}\left(\tilde{X}_{p}^{\prime} \tilde{X}_{p}\right)^{-1} \tilde{X}_{p}^{\prime}(I-S)+S_{F}$

(A7C) $S_{F}=S\left[I-X_{p}\left(\tilde{X}_{p}^{\prime} \tilde{X}_{p}\right)^{-1} \tilde{X}_{p}^{\prime}(I-S)\right]$.

Based on the linearity of $A 7 a$, we use results from Cleveland and Devlin (1988, p. 599) on the distribution of the residuals of LOESS regressions to estimate standard errors for $\beta_{\mathrm{p}}$ as proposed by Speckman (1988, $\mathrm{p}$.

421). We correct these standard errors for heteroskedasticity following W hite (1980).

We present the impact of each of the variables of the nonparametric part (partial impact) in so-called conditioning plots (Cleveland and Devlin, 1988). While one of these variables is set equal to its median, the other one is varied over all observations. Since the intercept in the estimated semiparametric model is not identified, only the changes in the values on the ordinate, not the values themselves, should be interpreted. The graphs we present include bands representing 90 percent confidence intervals. 
MARCH/ APRIL 1999

FEDERAL RESERVE BANK OF ST. LOUIS 